Ekspose Volume 16, Nomor 1, Januari - Juni 2017

P-ISSN: 1412-2715, E-ISSN: 2616-4412

\title{
IMPLEMENTASI UNDANG-UNDANG NOMOR 8 TAHUN 2016 TENTANG PENYANDANG DISABILITAS DALAM PERLINDUNGAN DAN PEMENUHAN HAK PENYANDANGDISABILITAS DI KABUPATEN BONE
}

\author{
Nur Paikah \\ Sekolah Tinggi Agama Islam Negeri Watampone, Bone, Indonesia \\ e-mail: nurpaikah@gmail.com
}

\begin{abstract}
The preamble of the 1945 Constitution philosophically and constitutionally, based on the basic philosophy of Pancasila and the 1945 Constitution, every citizen has equal opportunity in terms of employment, accessing public facilities, obtaining life and decent living, including for persons with disabilities. Law No. 8 of 2016 on Persons with Disabilities emphasizes that "Persons with disabilities are part of an Indonesian society with equal standing, rights, obligations and roles". Article 5 of Law no. 8 of 2016 on Persons with Disabilities that: "Every person with disabilities has equal rights and opportunities in all aspects of life and livelihood".
\end{abstract}

Keywords: Implementation, Disabilities, and Protection and Fulfillment of Rights

\section{Pendahuluan}

Pembukaan UUD tahun 1945 secara filosofis dan konstitusional, bertumpu pada dasar falsafah Pancasila dan UUD 1945, maka setiap warga negara memiliki kesempatan yang sama baik dalam hal pekerjaan, mengakses fasilitas umum, mendapatkan kehidupan dan penghidupan yang layak, termasuk pula bagi penyandang disabilitas.

Penyandang disabilitas berhak untuk bersaing dalam segala bidang kehidupan sesuai dengan jenis dan tingkat derajat kecacatannya. Berbekal pada kemampuan dan keterampilan yang dimiliki, tidak sedikit penyandang disabilitas bahkan berhasil mengangkat tingkat kesejahteraan dalam kehidupan yang lebih baik sesuai dengan bakat, minat dan kemampuannya. ${ }^{1}$

Peningkatan peran penyandang disabilitas dalam pembangunan nasional sangat penting untuk mendapat perhatian dan didayagunakan sebagaimana mestinya. Penyandang disabilitas memiliki kedudukan, hak dan kewajiban yang sama dengan masyarakat non disabilitas. Sebagai bagian dari warga negara Indonesia, sudah sepantasnya penyandang disabilitas mendapatkan perlakuan khusus, yang

\footnotetext{
${ }^{1}$ Undang-Undang Dasar Negara Republik Indonesia Tahun 1945 (Hasil Amandemen).
} 
dimaksudkan sebagai upaya perlindungan dari kerentanan terhadap berbagai tindakan diskriminasi dan terutama perlindungan dari berbagai pelanggaran hak asasi manusia. Dalam rangka mewujudkan jaminan dan perlindungan hak-hak penyandang disabilitas, Pemerintah semakin intensif dalam permasalahan penyandang disabilitas. Hal tersebut juga didukung dengan disahkannya Konvensi Hak-hak Penyandang Disabilitas, yang secara eksplisit, dituangkan dalam Undang-Undang Nomor 4 tahun 1997 tentang Penyandang Cacat yang kemudian diubah dalam Undang-Undang Nomor 12 Tahun 2011 dan terakhir diubah lagi dalam Undang-Undang Nomor 8 Tahun 2016 tentang Penyandang Disabilitas, yang secara khusus memberikan landasan hukum yang kuat dalam perjuangan persamaan hak bagi penyandang disabilitas.

Melalui Undang-Undang Nomor 8 Tahun 2016 tentang Pengesahan Konvensi Hak-hak Penyandang Disabilitas, merupakan langkah awal bagi penyandang disabilitas untuk memulai perjuangan yang baru untuk bisa hidup dengan lebih baik. Untuk itu, diperlukan keterlibatan semua pihak untuk berperan secara aktif dalam upaya pelaksanaannya, terutama mulai mengubah paradigma penanganan terhadap permasalahan penyandang disabilitas, yang semula dengan melaksanakan pendekatan kesejahteraan sosial telah diubah menjadi pola penanganan dengan pendekatan pemenuhan hak. Tentunya perubahan ini harus didukung dengan adanya fasilitas yang memadai sehingga pemenuhan hak tersebut dapat terwujud. ${ }^{2}$

Kepedulian dan keseriusan semua pihak sangat diharapkan khususnya jajaran Pemerintah Pusat, Pemerintah Provinsi, Pemerintah Kabupaten dan Kota serta seluruh lapisan masyarakat yang menjadi bagian dari struktur Negara, harus bersiap-siap melaksanakan tugasnya masing-masing dalam berbagai urusan termasuk urusan sosial dan tentu saja urusan penyandang disabilitasi menjadi tanggung jawab bersama mengimplementasikan undang-undang ini agar menjadi jalan memotong pelanggaran hak penyandang disabilitas yang terjadi baik di tingkat pusat maupun di daerah terkhusus di Kabupaten Bone.

Penyandang disabilitas di Kabupaten Bone berdasarkan data Dinas Kesejahteraan Sosial tercatat per Desember Tahun 2015 sebanyak 3.632 jiwa penyandang disabilitas yang tersebar di 27 kecamatan, bahkan Kabupaten Bone merupakan kota terbesar kedua setelah Makassar jumlah penyandang disabilitas. ${ }^{3}$ Realitasnya, jaminan dan perlindungan hak-hak penyandang disabilitas di Kabupaten Bone masih mengacu ke Undang-Undang Nomor 8 Tahun 2016 tentang Penyandang

\footnotetext{
${ }^{2}$ Penjelasan Umum UU no 8 tahun 2016 tentang Penyandang Disabilitas.

${ }^{3}$ Data Dinas Kesejahteraan Sosial Kabupaten Bone tahun 2015.
} 
Disabilitas, sedangkan tindak lanjut dari undang-undang ini di tingkat lokal masih dalam bentuk rancangan peraturan daerah (Ranperda) yang sementara masih dibahas di kantor DPRD Kabupaten Bone.

\section{Pengertian Penyandang Disabilitas}

Kata "Disabilitas" dalam Kamus Besar Bahasa Indonesia, belum tercantum. Disabilitas adalah istilah baru pengganti Penyandang Cacat. Penyandang Disabilitas dapat diartikan individu yang mempunyai keterbatasan fisik atau mental/intelektual. ${ }^{4}$ Istilah disabilitas masih kurang akrab di sebagian masyarakat Indonesia berbeda dengan "Penyandang Cacat", istilah ini banyak yang mengetahui atau sering digunakan di tengah masyarakat. Istilah Disabilitas merupakan kata bahasa Indonesia berasal dari serapan kata bahasa Inggris disability (jamak: disabilities) yang berarti cacat atau ketidakmampuan. ${ }^{5}$

Secara yuridis pengertian penyandang disabilitas diatur dalam Pasal 1 angka (1) Undang-Undang Nomor 8 Tahun 2016 tentang Penyandang Disabilitas, yaitu setiap orang yang mengalami keterbatasan fisik, intelektual, mental, dan atau sensorik dalam jangka waktu lama yang dalam berinteraksi dengan lingkungan dapat mengalami hambatan dan kesulitan untuk berpartisipasi secara penuh dan efektif dengan warga negara lainnya berdasarkan kesamaan hak. ${ }^{6}$

Dalam Undang-Undang Republik Indonesia No. 4 Tahun 1977 disebutkan tentang "Penyandang Cacat". Penyandang cacat seakan subyek hukum yang dipandang kurang diberdayakan. Istilah "Cacat" berkonotasi sesuatu yang negatif. Kata "penyandang" memberikan predikat kepada seseorang dengan tanda atau label negatif yaitu cacat pada keseluruhan pribadinya. Namun kenyataan bisa saja seseorang penyandang disabilitas hanya mempunyai kekurangan fisik tertentu, bukan disabilitas secara keseluruhan. Dalam Undang-Undang Disabilitas yang lama dalam hal ini Undang-Undang No. 4 tahun 1997 disebutkan tentang "Penyandang Cacat". Penyandang cacat seakan subyek hukum yang dipandang kurang diberdayakan. Istilah "Cacat" berkonotasi sesuatu yang negatif. Kata "penyandang" memberikan predikat kepada seseorang dengan tanda atau label negatif yaitu cacat pada keseluruhan pribadinya. $^{7}$ Namun kenyataan bisa saja seseorang penyandang disabilitas hanya mempunyai kekurangan fisik tertentu, bukan disabilitas secara

\footnotetext{
${ }^{4}$ Kamus Besar Bahasa Indonesia.

${ }^{5}$ Kamus Besar Bahasa Indonesia.

${ }^{6}$ UU No 8 Tahun 2016 tentang Penyandang Disabilitas.

${ }^{7}$ Pasal 1 ayat (1) UU No 4 Tahun 1997 tentang Penyandang Cacat.
} 
keseluruhan. Untuk itu istilah "cacat" dirubah menjadi "disabilitas" yang lebih berarti ketidakmampuan secara penuh.

\section{Hak Penyandang Disabilitas dan Ruang Lingkupnya}

Berlatar dari gambaran umum tentang penyadang disabilitas baik secara fisik maupun mental mengalami gangguan atau biasa disebut dengan disfugsi. Kekurangan inilah yang biasa dirasakan oleh penyandang disabilitas sebagai sebuah diskriminasi sehingga kerap memperoleh perlakuan yang tidak manusiawi. Padahal, seyogyanya penyandang disabilitas diperlakukan layaknya manusia biasa.

Diskriminasi juga kerap lahir karena perbedaan ideologi oleh beberapa kelompok tertentu. Namun, hal ini tidak berlaku bagi penyandang disabilitas. Mereka memperoleh perlakuan diskriminatif lantaran karena mereka berbeda secara fisik maupun mental. ${ }^{8}$ Persoalan yang timbul di berbagai kelompok masyarakat dalam bentuk kekerasan yang sama dengan dimulainya perlakuan berdasarkan pembedaan dengan target kelompok yang tidak berdasarkan etnis, ras, budaya, suku dan bahasa. Kelompok yang dimaksud di sini adalah anak-anak, perempuan penyandang disabilitas, orang lanjut usia, buruh, dan kelompok masyarakat adat terutama suku terasing. ${ }^{9}$

Penyandang disabilitas sama saja dengan manusia biasanya yang memerlukan kondisi lingkungan yang sehat dan tidak berada dalam kungkungan ketakutan akibat diskriminasi yang berkepanjangan. Padahal, manusia selayaknya manusia berhak mendapatkan perlakuan yang manusiawi. Juga bagi penyandang disabilitas yang harus diperlakukan sama dengan yang lainnya. ${ }^{10}$

Pelembagaan istilah kelompok khusus terutama penyandang disabilitas, memiliki konsekuensi secara sosioyuridis khususnya pada soal hak dan kedudukan dalam struktur sosial. Hal ini telah dilakukan oleh berbagai pihak untuk mendefinisikan hak-hak kelompok khusus dengan berbagai pendekatan. Salah satu bentuk pengkongkretan hak kelompok khusus dimaksud dari sudut hukum, dapat dijumpai pada memorandum yang dipersiapkan oleh Sekretaris Jenderal PBB 1950. Dalam memorandum tersebut antara lain ditegaskan bahwa interpretasi harfiah sudah tidak relevan untuk kondisi tertentu yang mana definisi mengenai kelompok khusus

\footnotetext{
${ }^{8}$ Natan Lerner, 1991, Diskriminasi dan Perlindungan HAM, terjemahan, (Jakarta: Sumber Baru), h. 23.

${ }^{9}$ Ruswiati Suryasaputra, 2006, Perlindungan Hak Asasi (Bagi kelompok khusus terhadap Diskriminasi dan Kekerasan), PTIK, Press Jakarta, h. 43.

${ }^{10}$ Saharuddin Dammin, "Paradigma perlakuan negara terhadap hak penyandang disabilitas", Disertasi, 2009, h. 23.
} 
sudah berkembang hingga kepada setiap jenis komunitas dalam suatu Negara. Komunitas yang dimaksud dapat saja keluarga, kelas sosial, kelompok secara kultural, dan lainnya. Oleh karena itu memorandum tersebut lalu menyatakan bahwa dibutuhkan definisi tertentu yang dapat memuat pengertian tentang komunitas yang membedakannya dengan kelompok penguasa. ${ }^{11}$

\section{Hak Penyandang Disabilitas dalam Konsep Negara Hukum}

Secara umum, orang selalu mengatakan bahwa keadilan adalah mengembalikan atau menempatkan sesuatu kepada tempatnya. Atau memberikan kepada seseorang sesuai haknya. Keadilan merupakan suatu kalimat yang mudah diucapkan tetapi tidak mudah untuk dirumuskan atau dilaksanakan. ${ }^{12}$ R.W.M. Dias dalam buku "Jurisprudence" berpandangan bahwa secara umum keadilan itu, didasarkan pada pengertian equality (persamaan). Di bidang perlakuan terhadap hukum harus diberikan perlakuan yang sama bagi setiap orang. Dalam kebijakan publik tidak dibenarkan adanya diskriminasi berdasarkan gender, status sosial, atau keyakinan agama. ${ }^{13}$

Munculnya, problem ini pada akhirnya membawa pada rumusan cita-cita keadilan berhubungan dengan peradaban. Pada dasarnya keberlakuan undang- undang bukan semata-mata karena terpenuhinya unsur keadilan, melainkan karena adanya unsur sanksi. Kepatuhan seseorang atas suatu peraturan hukum itu lebih utama karena peraturan hukum itu bersifat memaksa. Namun, meski demikian adanya, dalam suatu masyarakat yang menjunjung tinggi nilai demokratis, peraturan hukum yang dianggap oleh masyarakat bertentangan dengan keadilan, akan menghadapi protes keras dari masyarakat sehingga efektivitasnya akan terganggu.

Konvensi Internasional Hak-hak Penyandang Disabilitas terbentuk berdasarkan pada pertimbangan sebagaimana telah dinyatakan dalam prinsip-prinsip Piagam PBB yang mengakui martabat dan harkat yang melekat dan hak-hak yang setara dan tidak dapat dicabut dari semua anggota umat manusia sebagai dasar dari kebebasan, keadilan dan perdamaian di dunia. Dalam konvensi ini, PBB menegaskan kembali tentang makna universalitas, sifat tidak terbagi-bagi, kesalingtergantungan dan kesalingterkaitan antara semua hak asasi manusia dan kebebasan mendasar dan kebutuhan orang-orang penyandang cacat untuk dijamin sepenuhnya penikmatan atas

\footnotetext{
${ }^{11}$ Ruswiati Suryasaputra, Perlindungan Hak Asasi (Bagi kelompok khusus terhadap Diskriminasi dan Kekerasan), (Jakarta : PTIK Press, 2006), h. 15-16.

${ }^{12}$ Taufiqurrahman Syahuri, Tafsir Konstitusi Berbagai Aspek Hukum, (Jakarta : Kencana, 2011), h. 97.

${ }^{13}$ Taufiqurrahman Syahuri, Tafsir Konstitusi Berbagai Aspek Hukum, Kencana.
} 
hak asasi manusia dan kebebasan mendasar tersebut tanpa diskriminasi.

Konvensi Internasional Hak-hak Penyandang Disabilitas atau CRPD mempunyai tujuan untuk memajukan, melindungi dan menjamin penikmatan semua hak asasi manusia dan kebebasan mendasar secara penuh dan setara oleh semua orang penyandang cacat dan untuk memajukan penghormatan atas martabat yang melekat pada diri mereka. Orang-orang penyandang disabilitas termasuk mereka yang memiliki kerusakan fisik, mental, intelektual atau sensorik jangka panjang yang dalam interaksinya dengan berbagai hambatan dapat merintangi partisipasi mereka dalam masyarakat secara penuh dan efektif berdasarkan pada asas kesetaraan. ${ }^{14}$

Setelah berjuang sekian lama untuk memperoleh payung hukum terhadap perlindungan hak penyandang disabilitas, Sidang Paripurna DPR yang dihadiri seluruh fraksi dan Komisi VIII sepakat mengesahkan Convention on the Right of Persons with Disabilities (CRPD/ Konvensi mengenai Hak Penyandang Disabilitas) menjadi undang-undang pada hari Selasa tanggal 18 Oktober 2011 pukul 11.40 WIB. ${ }^{15}$ Menurut Menteri Luar Negeri Marty Natalegawa sebagaimana dikutip dalam tulisan pada yang berjudul "Pengesahan Ratifikasi CRPD: Sejarah Baru Jaminan Perlindungan Hak PD di Indonesia", pengesahan Konvensi mencerminkan komitmen dan kepedulian seluruh elemen bangsa bagi kemajuan hak asasi manusia khususnya terhadap kemajuan penyandang disabilitas yang wajib mendapatkan perhatian dari seluruh masyarakat Indonesia serta merupakan tanggung jawab Indonesia sebagai bagian dari masyarakat dunia dalam melindungi dan memajukan hak asasi manusia termasuk para penyandang disabilitas atau yang biasa dikenal dengan sebutan penyandang cacat. ${ }^{16}$

\section{Kendala yang Dihadapi dalam Perlindungan dan Pemenuhan Hak Penyandang Disabilitas di Kabupaten Bone}

Pemerintah Kabupaten Bone dalam hal ini Dinas Kesejahteraan Sosial telah melakukan beberapa upaya dalam melindungi dan memenuhi hak penyandang disabilitas, namun terkait hal ini masih banyak kendala yang dihadapi. Berdasarkan hasil wawancara dengan narasumber yang terkait ditemukan beberapa faktor yang berpengaruh terhadap kendala penerapan Undang-Undang No 8 tahun 2016 Tentang

\footnotetext{
${ }^{14}$ Bambang Sutiyoso, Konsepsi hak asasi manusia dan implementasinya di Indonesia, ( Jakarta :UII Press, 2002), h. 23.

${ }^{15}$ Ignas Triyono, Konskritisasi Universal Desain bagi akses penyandang disabilitas, Jurnal Hak Asasi Manusia Volume 4 No 2, Yogyakarta, Kementerian Hukum dan Hak Asasi Manusia, 2013, h. 13.

${ }^{16}$ Marjuki, Penyandang Disabilitas berdasarkan International Classification of Functioning for Disability and Health (ICF), 2013, h. 11
} 
Penyandang Disabilitas dalam perlindungan dan pemenuhan hak penyandang disabilitas di Kabupaten Bone sebagai berikut : ${ }^{17}$

\section{Faktor Subtansi Hukum}

Secara subtansi hukum adalah ketentuan-ketentuan yang mengatur mengenai perlindungan dan pemenuhan hak penyandang disabilitas khususnya di tingkat daerah masih sangat minim dalam hal ini masih mengacu pada Undang-Undang No 8 Tahun 2016 tentang Penyandang Disabilitas, padahal seyogyanya Pemerintah Kabupaten Bone mempunyai kebijakan untuk mewujudkan peraturan daerah tentang perlindungan dan pemenuhan hak penyandang disabilitas yang dapat menjadi landasan hukum.

Sebagai bentuk implementasinya hingga saat ini Pemerintah Kabupaten Bone belum memiliki peraturan yang terkait dengan penyandang disabilitas, belum dikuatkan dalam bentuk peraturan daerah yang secara khusus mengatur penyandang disabilitas di Kabupaten Bone tentunya berpengaruh terhadap implementasi Undang-Undang No 8 Tahun 2016 tentang Penyandang Disabilitas dalam melindungi dan memenuhi hak penyandang disabilitas di Kabupaten Bone belum terwujud dengan maksimal.

Akibatnya, penyandang disabilitas sebagai warga negara yang memiliki hak yang sama dengan warga negara lainnya tidak menikmati haknya sebagai warga negara secara maksimal dalam segala aspek kehidupan dan penghidupan disebabkan karena belum adanya regulasi khusus yang dijadikan sebagai standar perlindungan dan pemenuhan terhadap penyandang disabilitas yang ditetapkan oleh pemerintah setempat dalam hal ini Pemerintah Kabupaten Bone, diantaranya penyediaan aksebilitas fisik dan non fisik berdasakan kebutuhan penyandang disabilitas sesuai dengan jenis dan derajat disabelnya agar dapat memperoleh kesempatan yang sama sampai saat ini belum ada ketentuan baku atau standar yang menjadi acuan di setiap SKPD di Kabupaten Bone. Karena belum ditetapkan oleh pemerintah setempat dalam bentuk regulasi khusus.

\section{Faktor Struktur}

Struktur adalah pola yang memperlihatkan bagaimana hukum itu dijalankan menurut ketentuan formalnya, jadi struktur hukum memperlihatkan bagaimana aparat pemerintah beserta sarana dan prasaran yang mendukung

\footnotetext{
${ }^{17}$ Achmad Ali, Menjelajahi Kajian Empiris Hukum, (Jakarta : Yasrif Watampone,1998), h. 78
} 
terwujudnya perlindungan dan pemenuhan hak penyandang disabilitas di Kabupaten Bone. ${ }^{18}$

Adapun yang sangat terkait dalam penelitian ini adalah pihak pemerintah dalam hal ini Pemerintah Kabupaten khususnya Dinas Kesejahtraan Sosial beserta instansi yang terkait yang punya kewenangan menurut hukum untuk memberikan perlindungan dan pemenuhan hak bagi para penyandang disabilitas. Salah satu faktor yang menjadi penyebab tidak dilaksanakannya Undang-Undang No 8 tahun 2016 Tentang Penyandang Disabilitas dalam melindungi dan memenuhi hak penyandang disabilitas di Kabupaten Bone sebagaimana mestinya adalah berada pada sektor struktur hukum.

Hal ini disebabkan karena kurangnya pemahaman dan pengetahuan para aparat penegak hukum terhadap subtansi Undang-Undang No 8 tahun 2016 Tentang Penyandang Disabilitas khususnya dalam hal perlindungan dan pemenuhan hak penyandang disabilitas di Kabupaten Bone.

Selain itu, penyandang disabilitas belum secara maksimal memperoleh dan menikmati haknya seperti anggota masyarakat lainnya dalam berbagai aspek kehidupan dan penghidupan yang menghambat mobilitas dan kemandirianya, faktor penyebabnya karena minimnya sarana dan prasarana yang ada. Aksebilitas merupakan persoalan yang kerap dan hampir dialami seluruh penyandang disabilitas di Indonesia termasuk di Kabupaten Bone. Padahal idealnya penyandang disabilitas berpeluang untuk menikmati fasilitas umum baik gedung umum, kendaraan umum maupun segala bentuk fasilitas yang disediakan untuk warga umum.

Namun, realitasnya penyandang disabilitas di Kabupaten Bone belum mampu menikmati fasilitas umum karena minimnya alokasi anggaran pembangunan gedung yang layak dan mengakomodir penyandang disabilitas serta tidak adanya pedoman teknis fasilitas dan aksebilitas yang diajdikan acuan dan rujukan dalam melakukan pembangunan atau rehabilitasi gedung yang pro bagi penyandang disabilitas. Akibatnya, hampir seluruh fasilitas umum baik fisik maupun non fisik tidak layak bagi disabilitas.

Untuk itu, Pemerintah Kabupaten Bone perlu segera menganggarkan tersedianya sarana dan prasarana yang layak bagi penyandang disabilitas, namun fasilitas yang yang ada belum disesuaikan dengan kondisi dan kebutuhan penyandang disabilitas. Karena setiap disabilitas punya perbedaan

\footnotetext{
${ }^{18}$ Achmad Ali, Menguak Teori Hukum (Legal Theory) dan Teori Peradilan ((Judicialprudence). Edisi 1. (Jakarta: Penerbit Kencana, 2009), Cet. IV, h. 90.
} 
meski sama jenisnya. Pengetahuan mengetahui jenis disabilitas beserta keperluan dan kebutuhannya, saat ini belum layak bagi penyandang disabilitas

Di antaranya lembaga atau balai latihan kerja dalam bentuk Kelompok Usaha Bersama (KUBE), lembaga pembinaan dan advokasi, namun dinilai masih tidak aksebilitas terhadap penyandang disabilitas, diantaranya faktor sarana dan prasarana yang belum layak bagi penyandang disabilitas sehingga menjadi penghambat utama penyandang disabiliats mengikuti kegiatan pembinaan dan pelatihan, akhirnya berujung pada ketidak berlanjutannya aktivitas kerja dan tidak efektifnya advokasi atau pendampingan.

Kemudian jarak pelayanan dalam bentuk balai latihan kerja dan pembinaan mental yang dibentuk Dinas Kesejahteraan Sosial Kabupaten Bone menjadi salah satu hambatan dimana sarana transportasi juga tidak aksebilitas buat penyandang disabilitas.

3. Faktor Budaya Hukum

Budaya hukum sangat erat kaitannya dengan kesadaran hukum. Oleh karena itu, kesadaran hukum pemerintah, masyarakat dan penyandang disabilitas dalam mewujudkan perlindungan dan pemenuhan hak penyandang disabilitas merupakan faktor yang mempengaruhi penerapan Undang-Undang No 8 Tahun 2016 Tentang Penyandang Disabilitas dalam melindungi dan memenuhi hak penyandang disabilitas di Kabupaten Bone belum maksimal dalam ranah implementasinya.

Kesadaran hukum merupakan kesadaran atau nilai-nilai yang terdapat di dalam diri manusia tentang hukum yang diharapkan ada. Kesadaran hukum yang dimiliki oleh masyarakat tersebut akan mentaati suatu ketentuan hukum. Kesadaran seseorang bahwa melanggar ketentuan adalah suatu yang salah atau keliru, belum tentu membuat orang itu tidak melakukan pelanggaran jika pada saat itu perbuatan pelanggaran memungkinkan baginya. ${ }^{19}$

Kesadaran hukum yang baik adalah kesadaran hukum yang kemudian diikuti dengan ketaatan terhadap hukum. Ada tiga tingkatan kualitas ketaatan terhadap hukum yakni : ${ }^{20}$

1. Ketaatan hukum yang bersifat compliance, yaitu jika seseorang taat terhadap suatu aturan karena ia takut terkena sanksi

${ }^{19}$ Soerjono Soekanto, Kesadaran Hukum dan Kepatuhan Hukum, (Jakarta: Rajawali Press, 1982), h. 45.

${ }^{20}$ Soerjono Soekanto, Kesadaran Hukum dan Kepatuhan Hukum, h. 98. 
2. Ketaatan hukum yang bersifat identification, yaitu jika seseorang taat terhadap sesuatu aturan hukum hanya karena takut hubungan baiknya dengan seseorang rusak

3. Ketaatan hukum yang bersifat internalization, yaitu jika seseorang taat terhadap sesuatu aturan benar-benar karena ia merasa aturan itu sesuai dengan nilai-nilai intrinsik yang dianutnya.

Selanjutnya ada empat unsur yang dapat mendukung kesadaran dan ketaatan hukum, yakni :

1. Pengetahuan tentang hukum

2. Pengetahuan tentang isi hukum

3. Sikap hukum

4. Pola prilaku hukum

Berkaitan dengan kurangnya kesadaran dalam mentaati aturan, khususnya ketentuan Undang-Undang No 8 Tahun 2016 Tentang Penyandang Disabilitas dalam melindungi dan memenuhi hak penyandang disabilitas di Kabupaten Bone salah satu faktor penyebabnya adalah minimnya kualitas ketaatan dan tingkatan pencapaian pelaksanaan tugas aparat pemerintah. Oleh karena itu, ditaatinya suatu ketentuan bukanlah suatu ketentuan telah efektif dan diberlakukan. Akan tetapi perlu ditingkatkan menjadi suatu kebutuhan hukum (aturan) sehingga pelaksanaan ketentuan tersebut disadari dan ditaati dengan penuh kesadaran. Semakin banyak aparat pelaksana hukum yang melaksanakan hukum dengan ketaatan yang bersifat internalization, maka semakin tinggi implementasi hukum dalam kenyatannya.

Pemerintah Kabupaten Bone masih kurang memahami hak-hak dan kebutuhan penyandang disabilitas serta belum tergerak untuk berperan dalam pemenuhan kebutuhan hak penyandang disabilitas, hal yang dikeluhkan adalah promosi berupa sosialisasi yang dianggap kurang sesuai yang diharapkan dapat memudahkan dalam proses sosialisasi orang tua, dan masyarakat. Hasil wawancara dengan Kabid Pemberdayaan dan Rehabilitasi Sosial mengungkapkan bahwa instansi pemerintah daerah masih kurang memahami hak-hak dan kebutuhan penyandang disabilitas serta belum tergerak untuk berperan dalam pemenuhan kebutuhan hak penyandang disabilitas, hal yang dikeluhkan adalah promosi berupa sosialisasi yang dianggap kurang. Dinas Kesejahteraan Sosial Kabupaten Bone beserta pihak yang terkait dalam hal ini Dinas Tenaga kerja Transmigrasi, Dinas Kependudukan dan Catatan Sipil serta Dinas Pendidikan untuk dapat segera mungkin mensosialisasikan UndangUndang Nomor 8 Tahun 2016 tentang Penyandang Disabilitas dan Peraturan Pemerintah Republik Indonesia Nomor 43 Tahun 1998 Tentang Upaya Peningkatan 
Kesejahteraan Sosial Penyandang Disabilitas kepada semua pihak yang ada di Kabupaten Bone dengan lebih intensif lagi, supaya semua pihak tahu dan paham bahwa mereka mempunyai keharusan untuk melindungi dan memenuhi hak penyandang disabilitas.

Kendala lain yang turut mempengaruhi terimplementasinya Undang-Undang No 8 Tahun 2016 tentang Penyandang Disabiliats di Kabupaten Bone adalah kurangnya komunikasi yang baik antarsemua pihak yang bertanggung jawab dalam pelaksanaan perlindungan dan pemenuhan hak penyandang disabilitas di Kabupaten. Serta faktor perspektif pemerintah dan masyarakat kabupaten Bone yang masih berpikir picik dan sempit terhadap penyandang disabilitas dan faktor internal dari penyandang disabilitas itu sendiri yang cenderung kurang percaya diri dan menutup diri dari lingkungan masyarakat. Untuk meminimalisir kendala yang ada dalam mengimplememntasikan Undang-Undang No 8 Tahun 2016 tentang Penyandang Disabilitas dalam melindungi dan memenuhi hak penyandang disabilitas di Kabupaten Bone, maka upaya yang harus dilakukan agar implementasi UndangUndang No 8 tahun 2016 Tentang Penyandang Disabilitas di Kabupaten Bone dapat terwujud secara optimal antara lain:

1. Perlu adanya penguatan Undang-Undang Nomor 8 Tahun 2016 tentang Penyandang Disbailtas dalam bentuk perda karena undang-undang tersebut bersifat umum dan harus disesuaikan dengan kondisi dan budaya. Kemudian diterbitkan sebagai bentuk peraturan daerah Kabupaten Bone sehingga bisa menjadi payung hukum yang jelas bagi semua pihak dan terkhusus bagi penyandang disabiliats di Kabupaten Bone, sehingga hak mereka menjadi jelas.

2. Pemerintah Kabupaten Bone sesegera mungkin meningkatkan sosialisasi undang-undang tentang penyandang disabilitas terutama meningkatkan sarana aksesibilitas, memberikan pelatihan dan pendidikan kepada penyandang disabilitas untuk menunjang penyandang disabilitas dalam hal mendapatkan pekerjaan serta merubah stigma atau pandangan. Dengan cara memberikan motivasi kepada penyandang disabilitas maka dia mampu dan sama dengan orang normal lainnya.

3. Pemerintah Kabupaten Bone dalam hal ini Dinas Kesejahteraan Sosial Kabupaten Bone perlu melakukan kerjasama dengan semua pihak yang terkait dalam hal ini Dinas Tenaga kerja Transmigrasi, Dinas Kependudukan dan Catatan Sipil serta Dinas Pendidikan untuk dapat segera mungkin bekerjasama mensosialisasikan Undang- Undang Nomor 8 Tahun 2016 tentang Penyandang Disabilitas dan Peraturan Pemerintah Republik Indonesia Nomor 43 Tahun 1998 Tentang Upaya Peningkatan Kesejahteraan Sosial Penyandang Disabilitas 
kepada semua pihak yang ada di Kabupaten Bone dengan lebih intensif lagi, supaya semua pihak tahu dan paham bahwa mereka mempunyai keharusan untuk melindungai dan memenuhi hak penyandang disabilitas.

4. Pemerintah Kabupaten Bone harus mendorong tersedianya sarana dan prasarana yang layak untuk Penyandang Disabilitas, saat ini belum terlaksana dengan baik, bahkan jauh dari yang diharapkan. Hal ini terbukti dengan masih banyaknya fasilitas umum penyandang yang tidak layak dan mengakomodir kebutuhan penyandang disabilitas. Hal ini disebabkan karena pemerintah kurang mengetahui, bahkan tidak mengetahui sama sekali undang-undang yang menjelaskan tentang perlindungan dan pemenuhan hak penyandang disabilitas untuk memperoleh hak aksebilitas yang layak bagi penyandang disabilitas.

5. Perlunya adanya pengawasan dan ketegasan dari pemerintah agar UndangUndang Nomor 8 Tahun 2016 tentang Penyandang Disabilitas dapat di implementasikan dengan baik, sehingga semua pihak dapat menunaikan kewajibannya dengan baik dan penyandang disabilitas mendapatkan haknya di segala bidang. Selain itu, diperlukan pula pengawasan dari pihak ketiga seperti organisasi penyandang disabilitas, yang berfungsi untuk memantau dan mengawasi kinerja pemerintah dalam hal ini dinas kesejahteraan sosial dalam menangani masalah hak penyandang disabilitas, serta juga untuk memperjuangkan hak penyandang disabilitas dalam mendapatkan haknya.

\section{Simpulan}

Berdasarkan uraian dari hasil penelitian dan pembahasan, maka disimpulkan bahwa Implementasi Undang-Undang No 8 Tahun 2016 tentang penyandang disabilitas dalam perlindungan dan pemenuhan hak penyandang disabilitas di Kabupaten Bone tidak sepenuhnya berjalan dengan maksimal. Hal ini dikarenakan belum dikuatkannya Undang-Undang No 8 Tahun 2016 Tentang Penyandang Disabilitas dalam bentuk ketentuan khusus yang dituangkan dalam Perda Bone khusus mengatur mengenai perlindungan dan pemenuhan hak penyandang disabilitas di Kabupaten Bone. Selain itu, masih minimnya kegiatan sosialisasi hukum terhadap aparat pemerintah Kabupaten Bone, masyarakat dan juga para penyandang disabilitas terhadap keberadaan Undang-Undang No 8 tahun 2016 tentang Penyandang disabilitas khususnya sosialisasi terhadap substansi undang-undang.

Ada tiga faktor utama yang menjadi kendala dalam mengimplementasikan Undang-Undang No 8 Tahun 2016 Tentang Penyandang Disabilitas. Faktor pertama merupakan faktor dari sudut struktur hukum atau substansi hukum yang masih minim yang khusus mengatur penyandang disabilitas di Kabupaten Bone. Faktor kedua 
adalah sarana dan prasarana serta kapasitas aparat pemerintah yang masih kurang pihak substansi undang-undang penyandang disabilitas serta minimnya sarana danp prasarana yang layak bagi penyandang disabilitas. Faktor ketiga adalah budaya hukum pemerintah, aparat, masyarakat dan diri penyandang disabilitas meliputi derajat disabilitas, pendidikan, dan kemiskinan, sementara dari luar diri penyandang disabilitas yang meliputi keluarga, diskriminasi masyarakat, keterbatasan anggaran masyarakat, keterbatasan anggaran pemerintah, dan bantuan.

\section{Daftar Pustaka}

Ali, Achmad. Menguak Teori Hukum (Legal Theory) dan Teori Peradilan (Judicialprudence). Edisi 1. Cet. IV; Jakarta: Penerbit Kencana, 2009.

Ali, Achmad. Menjelajahi Kajian Empiris Hukum, Yasrif Watampone, Jakarta, 1998.

Dammin, Saharuddin. Paradigma perlakuan negara terhadap hak penyandang disabilitas, Disertasi, 2009, h. 23

Data Dinas Kesejahteraan Sosial Kabupaten Bone tahun 2015.

Kamus Besar Bahasa Indonesia

Konvensi PBB tentang Penyandang Disabilitas

Marjuki, Penyandang Disabilitas berdasarkan International Classification of Functioning for Disability and Health (ICF), 2013, h. 11

Natan Lerner, 1991, Diskriminasi dan Perlindungan HAM, terjemahan. Jakarta: Sumber Baru.

Ruswiati Suryasaputra, 2006, Perlindungan Hak Asasi (Bagi kelompok khusus Terhadap Diskriminasi dan Kekerasan), PTIK, Press Jakarta.

Soekanto, Soerjono Kesadaran Hukum dan Kepatuhan Hukum. Jakarta Rajawali Press, 1982.

Suryasaputra, Ruswiati. 2006, Perlindungan Hak Asasi (Bagi kelompok khusus Terhadap Diskriminasi dan Kekerasan), PTIK, Press Jakarta.

Sutiyoso, Bambang. Konsepsi hak asasi manusia dan implementasinya di Indonesia, UII Press, Jakarta, 2002.

Syahuri, Taufiqurrahman. Tafsir Konstitusi Berbagai Aspek Hukum, Kencana, Jakarta, 2011. 
Ekspose Volume 16, Nomor 1, Januari - Juni 2017

P-ISSN: 1412-2715, E-ISSN: 2616-4412

Triyono, Ignas Konskritisasi Universal Desain bagi akses penyandang disabilitas, Jurnal Hak Asasi Manusia Volume 4 No 2, Yogyakarta, Kementerian Hukum dan Hak Asasi Manusia, 2013.

Undang-Undang Dasar Negara Republik Indonesia Tahun 1945.

UU No 8 Tahun 2016 tentang Penyandang Disabilitas

UU No 4 Tahun 1997 tentang Penyandang Cacat

Penjelasan Umum Konvensi PBB tentang Penyandang Disabilitas

Penjelasan umum UU No 8 Tahun 2016 tentang Penyandang Disabilitas 